\title{
Substitution of Pennisetum purpureum by Opuntia ficus-indica and Mimosa tenuiflora in the diet of lambs ${ }^{1}$
}

\author{
Substituição do "Pennisetum purpureum" por "Opuntia ficus-indica" $e$ "Mimosa \\ tenuiflora" na dieta de ovinos ${ }^{I}$
}

\begin{abstract}
CORDÃO, Maiza Araújo ${ }^{2}$; BAKKE, Olaf Andreas ${ }^{3 *}$; PEREIRA, Gabriella Marinho ${ }^{3}$; SILVA, Aderbal Marcos de Azevedo ${ }^{3}$; NÓBREGA, Giovanna Henriques da ${ }^{2}$; CAMPOS, Édipo Moreira ${ }^{3}$; PEREIRA, Hélio Domingos ${ }^{3}$; PEREIRA FILHO, José Morais ${ }^{3}$
\end{abstract}

\footnotetext{
${ }^{1}$ Pesquisa patrocinada pela CAPES, projeto PROCAD-NF 1431/2007.

${ }^{2}$ Universidade Federal de Campina Grande, Centro de Saúde e Tecnologia Rural, Programa de PósGraduação em Medicina Veterinária, Patos, Paraíba, Brasil.

${ }^{3}$ Universidade Federal de Campina Grande, Centro de Saúde e Tecnologia Rural, Patos, Paraíba, Brasil.

*Endereço para correspondência: maizacordao@ hotmail.com
}

\section{SUMMARY}

The objectives of this study were to quantify the apparent digestibility of the diet components and the performance of lambs consuming increasing levels of the balanced (weight) mixture of Opuntia ficus indica bran and Mimosa tenuiflora leaves and fine branches hay substituting 0,33 and $67 \%$ of Pennisetum purpureum hay, in a $60 \%$ roughage fodder to $40 \%$ concentrate diet formulated to a daily live body weight gain of $150 \mathrm{~g} / \mathrm{animal}$. Experiment was carried out at UFCG facilities, in Patos-PB, using 18 non-emasculated lambs with $(20.4 \pm 1.16) \mathrm{kg}$ (mean weight $\pm \mathrm{SE})$. Dry matter, $\mathrm{OM}, \mathrm{CP}, \mathrm{EE}$ and total carbohydrates $\mathrm{CD}$ were affected by the levels of the mixture $(\mathrm{P}<0.05)$ according to a second degree model, with minimum CD values between 34 and $52 \%$ of $P$. purpureum hay replacement. Neutral detergent fiber and $\mathrm{ADF} C \mathrm{CD}$ decreased linearly $(\mathrm{P}<0.05)$, and those for CE and NFC were not affected $(\mathrm{P}>0.05)$. The inclusion of the mixture affected linear and positively the daily mean body weight gain (120, 149 and 170 g/animal, respectively for 0,33 and $67 \% P$. purpureum hay replacement levels), and $\mathrm{DM}, \mathrm{OM}, \mathrm{CP}$, $\mathrm{TCH}$ and NFC consumptions. The balanced mixture of Opuntia ficus indica bran and Mimosa tenuiflora hay can replace up to $67 \%$ of the roughage fodder fraction ( $P$. purpureum) of Santa Inês lamb diet and improve the daily body weight gain by $50 \mathrm{~g} / \mathrm{animal}$.

Keywords: cactus, small ruminants, tree fodder

\section{RESUMO}

Os objetivos deste estudo foram quantificar a digestibilidade aparente dos componentes da dieta e o desempenho de cordeiros alimentados com níveis crescentes de uma mistura balanceada (peso) de farelo de Opuntia ficus indicae e feno de Mimosa tenuiflora em substituição a 0, 33 e 67\% do feno Pennisetum purpureum, em uma dieta com $60 \%$ de volumoso e $40 \%$ de concentrado, formulada para um ganho de peso diário de 150 g/animal. O experimento foi conduzido na UFCG, Patos-PB, usando 18 cordeiros inteiros com $(20,4 \pm 1,16) \mathrm{kg}$ (peso médio $\pm \mathrm{EP})$. O CD da MS, $\mathrm{MO}, \mathrm{PB}, \mathrm{EE}$ e dos carboidratos totais foram afetados pelos níveis da mistura $(\mathrm{P}<0,05)$ de acordo com um modelo quadrático, com mínimo valor de CD entre 34 e $52 \%$ de substituição do feno de $P$. purpureum. A digestibilidade da FDN e da FDA decresceu linearmente $(\mathrm{P}<0,05)$, e as da EB e dos carboidratos não fibrosos não foram afetadas $(\mathrm{P}>0,05)$. A inclusão da mistura afetou linear e positivamente o ganho de peso médio diário $(120,149$ e 170g/animal, respectivamente para 0,33 e $67 \%$ de substituição do feno de $P$. purpureum), e o consumo de MS, MO, PB, carboidratos totais e não fibrosos. A mistura balanceada do farelo de Opuntia fícus indica e do feno de Mimosa tenuiflora pode substituir até $67 \%$ da fração volumosa ( $P$. purpureum) da dieta de cordeiros Santa Inês e melhorar o ganho de peso médio diário em 50g/animal.

Palavras-chave: cactácea, forragem arbórea, pequenos ruminantes 


\section{INTRODUCTION}

Approximately $1.6 \%$ (16.2 million) of the world sheep population grows in Brazil, mostly in its tropical semiarid northeast region (IBGE, 2007) in which the Caatinga vegetation predominates. These natural seasonal herbaceous and perennial shrub and tree communities provide most of the forage consumed by sheep in the rainy season, however during the dry season food is scarce (ZIGUER et al., 2011), and animals need to be supplemented. Pennisetum purpureum Schumach is a water and soil demanding grass used to feed ruminants in Brazil, but its growth and quality decrease in the 7-to-8-month long dry season of the tropical semiarid region of northeast Brazil (CAMURÇA et al., 2002), and ranching should be based on xerophytes such as the cactus Opuntia ficus-indica Mill and the legume tree Mimosa tenuiflora (Willd.) Poiret (CASTRO et al., 2007).

The mentioned cactus is adapted to the dry tropical region of northeast and is capable to produce a palatable forage rich in non fibrous carbohydrates Brazil (VERAS et al., 2002; MELO et al., 2003). Cattle, goat and sheep consume it as a substitute of the concentrate (up to $75 \%$ ) or roughage (up to $56 \%$ ) fraction of the diet (VERAS et al., 2002; BISPO et al., 2007).

The mentioned legume tree occurs naturally in the Caatinga and its fine branches and fruits are protein rich and palatable to ruminants (MAIA, 2004; MOREIRA et al., 2006). Although in vitro digestibility of $M$. tenuiflora fine branches is low $(<22 \%)$, depending on the vegetative stage (MOREIRA et al., 2006) and the presence of compounds such as condensed tannins (BEELEN et al., 2006). Cordão et al. (2008) reported body weight gain of $1.14 \mathrm{~kg}$ in a 56 day experiment with Santa Ines sheep fed $33 \% \quad M$. tenuiflora and $66 \% \quad P$. purpureum hay.

This study determined the apparent digestibility of the components of the diets and the performance of Santa Inês lambs fed increasing levels $(0,33$ and $67 \%$ ) of the balanced (weight) $O$. fícus indica and $M$. tenuiflora fine branches hay mixture $[(\mathrm{Op}+\mathrm{Mim}) \operatorname{mix}]$ as a substitute of $P$. purpureum hay.

\section{MATERIAL AND METHODS}

This study was carried out at the Federal University of Campina Grande, Patos-PB, Brazil, from November/2009 to January/2010. Mean daily maximum and minimum temperatures were 38.8 and $24.5^{\circ} \mathrm{C}$, respectively. Air moisture averaged $76.2 \%$ at $09: 00 \mathrm{~h}$ and $39.9 \%$ at 15:00 h. Composition of $P$. purpureum and M. tenuiflora hay, ground corn, and $O$. ficus-indica, wheat and soya bran (Table 1) were determined and roughage fodder and concentrate comprised $60 \%$ and $40 \%$ of the diets, respectively (Table 2 ).

Pennisetum purpureum hay came from approximately 100-day-growth plants that were cut, chopped and sun-dried (10-to-12\% moisture). Cladodes were harvested in September 2008, cut in 3 $\mathrm{cm}$ wide pieces and sun-dried. Leaves and 10 -to- $15 \mathrm{~mm}$ thick branches were cut from $M$. tenuiflora trees at full growth stage in May and June 2009, and processed similarly to $P$. purpureum. Dried materials were reprocessed separately in a chopper machine with a $5 \mathrm{~mm}$-mesh sieve.

Experimental diets [0, 33 and $67 \%$ substitution of $P$. purpureum hay by the balanced (weight) (Op+Mim)mix], adjusted to $150 \mathrm{~g}$ of daily body weight gain / lamb (NRC, 2007) were assigned to eighteen non-emasculated, $20.4 \mathrm{~kg} \pm$ 
$1.2 \mathrm{~kg}$ (mean weight $\pm \mathrm{SE}$ ), three-monthold Santa Inês lambs, according to a complete block (lamb weight) design with six replications and 18 plots (18 lambs).

The 77-day performance trial had an initial 14-day adaptation period and a 63-day period of data collection during which each lamb was confined in $1.30 \mathrm{~m}$ $\mathrm{x} 0.75 \mathrm{~m}$ wood stalls with individual water and food supplies. Experimental diets were supplied twice a day ( $7 \mathrm{~h}$ e $14 \mathrm{~h}$ ), with a daily $20 \%$ surplus of the quantity consumed in the previous day. Daily body weight gain was determined by the difference between the final and initial body weights divided by the number of days of the experimental period (63 days). Individual daily water and solid food consumptions were determined by the difference between the offered and unconsumed quantities. Water consumption was corrected by the average evaporation measured in two recipients similar to the ones present in each stall.

Offered and unconsumed solid food was sampled daily for each animal. These samples were mixed and analyzed for DM, OM, NDF, ADF, $\mathrm{CP}$ and EE (DETMANN et al., 2012). For $O$. fícus indica and soya bran, NDF was determined according to Van Soest et al. (1991) recommendations. Contents of NDF and ADF were corrected for ashes and proteins (SNIFFEN et al., 1992). Total carbohydrate was estimated by $\% \mathrm{TC}=100-(\% \mathrm{CP}+$ $\%$ EE $+\%$ Ashes), NFC by $\%$ NFC $=$ $\%$ TC - \%NDFcp (HALL, 1999), ME by $\mathrm{ME}=$ ingested $\mathrm{CE}-($ fecal $\mathrm{CE}+\mathrm{CE}$ in urine $+\mathrm{CE}$ in excreted gases), and $\mathrm{CE}$ in excreted gases $=\mathrm{GPc} \mathrm{x}$ ingested $\mathrm{CE} /$ 100 , and $\mathrm{GPc}=$ Gas production $=4.28$ $+0.059 * \mathrm{CDCE}(\mathrm{CDCE}=$ coefficient of digestibility of crude energy) (BLAXTER, 1962).

Table 1. Bromatological composition of the ingredients used in the experimental diets

\begin{tabular}{lcccccc}
\hline $\begin{array}{c}\text { Composition } \\
(\% \text { DM })\end{array}$ & $\begin{array}{c}\text { P. purpureum } \\
\text { hay }\end{array}$ & $\begin{array}{c}\text { O. ficus indica } \\
\text { bran }\end{array}$ & $\begin{array}{c}\text { M. tenuiflora } \\
\text { hay }\end{array}$ & $\begin{array}{c}\text { Soya } \\
\text { bran }\end{array}$ & $\begin{array}{c}\text { Ground } \\
\text { corn }\end{array}$ & $\begin{array}{c}\text { Whea } \\
\text { tbran }\end{array}$ \\
\hline DM & 94.03 & 91.60 & 92.72 & 92.87 & 91.81 & 93.10 \\
Ashes & 10.11 & 11.55 & 3.78 & 7.58 & 10.19 & 5.85 \\
OM & 89.89 & 88.45 & 96.22 & 92.42 & 89.81 & 94.15 \\
CP & 4.28 & 10.20 & 8.27 & 47.26 & 8.86 & 14.77 \\
NDFap & 78.56 & 30.70 & 58.16 & 18.04 & 14.45 & 39.37 \\
ADFap & 47.56 & 15.22 & 51.26 & 11.05 & 6.54 & 24.46 \\
CE(Mcal/kg) & 4.459 & 4.366 & 4.926 & 4.936 & 4.824 & 4.912 \\
EE & 5.94 & 3.09 & 6.53 & 4.37 & 5.45 & 6.83 \\
TC & 79.66 & 75.16 & 81.42 & 40.79 & 75.49 & 72.55 \\
NFC & 1.10 & 44.46 & 23.26 & 22.75 & 61.04 & 33.18 \\
TP & & - & 15.0 & - & - & - \\
TT & & - & 10.4 & - & - & - \\
CT & & - & 6.26 & - & - & - \\
Ca & 0.78 & 4.10 & 1.05 & 0.93 & 0.78 & 0.49 \\
P & 0.019 & 0.017 & 0.056 & 0.057 & 0.027 & 0.077 \\
\hline
\end{tabular}

$\mathrm{DM}=$ dry matter, $\mathrm{OM}=$ organic matter, $\mathrm{CP}=$ crude protein, $\mathrm{NDFap}=$ neutral detergent fiber corrected for ashes and protein, ADFap $=$ acid detergent fiber corrected for ashes and protein, $\mathrm{CE}=$ crude energy, $\mathrm{EE}=$ ether extract, $\mathrm{TC}=$ total carbohydrates, $\mathrm{NFC}=$ non fibrous carbohydrates, $\mathrm{TP}=$ total phenols, $\mathrm{TT}=$ total tannins, $\mathrm{CT}=$ condensed tannins, $\mathrm{Ca}=$ calcium, $\mathrm{P}=$ phosphorus . 
Table 2. Proportion of the ingredients and chemical composition (\%DM) of the experimental diets, according to the levels of $P$. purpureum substitution by the balanced (weight) mixture of $O$. fícus indica bran and $M$. tenuiflora hay

\begin{tabular}{lrrr}
\hline \multirow{2}{*}{ Ingredients } & \multicolumn{3}{c}{ Substitution levels of P. purpureum } \\
\cline { 2 - 4 } & $0 \%$ & $33 \%$ & $67 \%$ \\
\hline P. purpureum hay & 60.00 & 40.00 & 20.00 \\
M. tenuiflora hay & 0.00 & 10.00 & 20.00 \\
O. ficus indica bran & 0.00 & 10.00 & 20.00 \\
Soya bran & 20.00 & 20.00 & 20.00 \\
Ground corn & 10.00 & 8.00 & 8.50 \\
Wheat bran & 9.00 & 11.30 & 11.00 \\
Mineral mixture & 1.00 & 0.70 & 0.50 \\
\hline Total & 100.00 & 100.00 & 100.00 \\
\hline Chemical composition (\%) & & & 92.78 \\
\hline Dry matter & 93.53 & 93.17 & 42.46 \\
Organic Matter & 90.02 & 90.83 & 27.16 \\
Neutral detergent fiber* & 55.73 & 49.52 & 16.38 \\
Acid detergent fiber* & 33.27 & 30.44 & 4.69 \\
Crude protein & 14.24 & 15.39 & 5.20 \\
Crude energy (Mcal/kg) & 4.59 & 4.64 & 69.88 \\
Ether extract & 5.60 & 5.42 & 27.23 \\
Total carbohydrates & 70.18 & 70.02 & 3.81 \\
Non fibrous carbohydrates & 14.45 & 20.50 & 2.62 \\
Total phenols & 1.01 & 2.30 & 1.060 \\
Total tannins & 0.66 & 1.68 & \\
Condensed tannins & 0.028 & 0.424 & \\
\hline Corrected for ashes & & & \\
\hline
\end{tabular}

*Corrected for ashes and protein.

Digestibility trial lasted 21 days (16-day adaptation period, and five days for total urine and feces collection and sampling of offered and unconsumed food). During this period, each lamb was confined in $1.00 \mathrm{~m} \times 0.60 \mathrm{~m}$ metabolic cages with individual water and food supplies. Experimental diets were supplied twice a day $(07: 00 \mathrm{~h}$ e 14:00 h), with a daily $20 \%$ surplus of the quantity consumed in the previous day.

Statistical analysis were performed on the coefficients of apparent digestibility and daily consumptions data sets of dry matter (CDDM and CDM, respectively), organic matter (CDOM and $\mathrm{COM}$ ), neutral (CDNDF and CNDF) and acid detergent fiber (CDADF and $\mathrm{CADF}$ ), crude protein ( $\mathrm{CDCP}$ and $\mathrm{CCP}$ ), crude energy (CDCE and CCE), ether extract (CDEE and CEE), and total (CDTC and CTC) and non fibrous carbohydrates (CDNFC and CNFC). Daily body weight gain (BWG), consumption of metabolizable energy (CME) and water $(\mathrm{CW})$, and food conversion $(\mathrm{FC}=$ mean daily consumption of $\mathrm{DM} /$ mean daily body weight gain)) were also considered. Total feces excreted by each lamb were weighed daily to estimate the coefficients of apparent digestibility. Similarly, total urine was collected in a plastic pail with $10 \mathrm{~mL}$ of a $50 \%$ chloride acid solution, to estimate metabolizable energy.

The coefficients of digestibility (CD) of each bromatological component of the diet were estimated by:

$$
\mathrm{CD} \%=\frac{\text { (Consumed Quantity - Excreted Quantity in feces) } \times 100}{\text { Consumed Quantity }}
$$


Prior to analysis of variance, homogeneity of variance between treatments was checked by $\mathrm{F}_{\max }$ test, and Regression Analysis was applied to correlate the levels of $P$. purpureum substitution by $(\mathrm{Op}+\mathrm{Mim}) \mathrm{mix}$ and the studied variables using, respectively, the GLM and the GSR routine of Statistica $7.0(\mathrm{P}=0.05)$ - (STATSOFT, 2005).

\section{RESULTS AND DISCUSSION}

Inclusion of $(\mathrm{Op}+\mathrm{Mim}) \mathrm{mix}$ increased linearly BWG, CDM, COM and CCP (Table 3), especially when expressed in units of metabolic body weight $\left(\mathrm{g} / \mathrm{kg}^{0.75}\right) \quad\left(\mathrm{r}^{2}>0.62\right)$. Consumption of Metabolic Energy and Food Conversion were not affected. Regression equation indicated that BWG increases approximately $0.75 \mathrm{~g} / \mathrm{animal}$.day to each percentage point of substitution of $P$. purpureum hay, or equivalently, the substitution of $67 \%$ of $P$. purpureum by the $(\mathrm{Op}+\mathrm{Mim}) \mathrm{mix}$ adds up an average of $50 \mathrm{~g}$ to the daily body weight gain of Santa Inês lambs.

The observed mean values for BWG are comparable to the values reported by Parente et al. (2009) (BWG $=171.6 \mathrm{~g} /$ animal.day) for $1 / 2$ Santa Inês $x \quad 1 / 2$ undefined breed fed a $31 \%$ concentrate: $69 \%$ Tifton grass diet, and surpassed the ones by Camurça et al. (2002) (BWG = 87 to $117 \mathrm{~g} /$ animal.day) for Santa Ines lambs fed $30 \%$ concentrate and $70 \%$ Cenchrus ciliaris or Urochloa mosambicensis or Panicum molle grass hay. However, the tree Manihot glaziovii Muell. Arg. produces protein rich, palatable leaves that can be used in a $60 \%$ roughage fodder: $40 \%$ concentrate diet and result in average BWG of $253.35 \mathrm{~g} /$ Santa Inês lamb (CASTRO et al. 2007).

Table 3. Means, regression equations for the variables (Y) daily body weight gain (BWG), consumptions of dry matter (CDM), organic matter (COM), crude protein (CCP) and metabolic energy (CME), and food conversion (FC), according to the level (X) of substitution of Pennisetum purpureum hay by the balanced mixture of Opuntia ficus indica bran and Mimosa tenuiflora fine branches hay $[(\mathrm{Op}+\mathrm{Mim}) \mathrm{mix}]$ in the diet of Santa Ines male lambs, and respective levels of significance $(\mathrm{P})$ and coefficients of determination $\left(\mathrm{r}^{2}\right)$

\begin{tabular}{|c|c|c|c|c|c|c|}
\hline \multirow[t]{2}{*}{ Variables } & \multicolumn{3}{|c|}{$\begin{array}{l}\text { Levels (X) of substitution of P. } \\
\text { purpureum by (Op+Mim)mix }\end{array}$} & \multirow{2}{*}{$\begin{array}{l}\text { Regression } \\
\text { Equation }\end{array}$} & \multirow[t]{2}{*}{$\mathrm{P}$} & \multirow[t]{2}{*}{$\mathrm{r}^{2}$} \\
\hline & $X=0 \%$ & $X=33 \%$ & $X=67 \%$ & & & \\
\hline BWG (g/an.day*) & 120.0 & 149.0 & 170.0 & $Y=120.53+0.75 X$ & 0.007 & 0.396 \\
\hline CDM (g/an.day) & 982.0 & 1141.8 & 1252.6 & $Y=990.99+4.04 X$ & 0.027 & 0.271 \\
\hline $\operatorname{CDM}\left(\mathrm{g} / \mathrm{kg}^{0.75}\right)$ & 90.8 & 102.5 & 110.00 & $Y=91.59+0.29 X$ & 0.000 & 0.628 \\
\hline COM (g/an.day) & 880.0 & 1034.8 & 1146.1 & $Y=888.03+3.97 X$ & 0.018 & 0.304 \\
\hline $\mathrm{COM}\left(\mathrm{g} / \mathrm{kg}^{0.75}\right)$ & 81.3 & 92.8 & 100.33 & $Y=82.06+0.28 X$ & 0.000 & 0.677 \\
\hline CCP (g/an.day) & 150.2 & 183.8 & 209.33 & $Y=151.70+0.88 X$ & 0.004 & 0.416 \\
\hline $\mathrm{CCP}\left(\mathrm{g} / \mathrm{kg}^{0.75}\right)$ & 13.8 & 16.7 & 18.2 & $Y=14.07+0.07 X$ & 0.000 & 0.728 \\
\hline CME (Mcal/day) & 2.7 & 2.6 & 2.5 & $Y=2.61$ & 0.702 & 0.010 \\
\hline CME (Mcal/kg $\left.{ }^{0.75}\right)$ & 0.24 & 0.23 & 0.22 & $Y=0.23$ & 0.319 & 0.066 \\
\hline $\mathrm{FC}$ & 8.20 & 7.78 & 7.35 & $Y=7.77$ & 0.325 & 0.064 \\
\hline
\end{tabular}

$*$ g/an.day $=$ g/animal.day. 
The linear positive effect of the (Op+Mim)mix on CDM was certainly due to the palatability and NFC of Opuntia bran (Table 1), and had a positive effect on BWG. Observed total daily CDM increased from 982.03 g/animal.day, for $\mathrm{X}=0 \%$, to 1252.60 g/animal.day, for $X=67 \%$ (Table 3). These values are higher than the reported by Camurça et al. (2002): $\mathrm{CDM}=871.43,787.30,943.14$ or 1044.11g/animal.day for Santa Inês lambs fed $70 \%$ P. purpureum, Cenchrus ciliaris L., cv. Aridus, Urochloa mosambicensis Hack-Daudy or Panicum molle Swartz, respectively, and 30\% concentrate, and are similar to the reported by Castro et al. (2007): $1160 \mathrm{~g} /$ animal.day $\leq \mathrm{CDM} \leq 1220 \mathrm{~g} / \mathrm{animal}$. day for Santa Inês lambs fed $M$. glaziovii hay (20 to $80 \%$ of the $60 \%$ roughage fodder fraction of the diet).

Consumption of crude protein increased linearly $(\mathrm{P}<0.05)$ whith $P$. purpureum hay substitution (Table 3). Values for CCP (from 150.16 to $209.33 \mathrm{~g} / \mathrm{animal}$.day or from 13.83 to $18.16 \mathrm{~g} / \mathrm{kg}^{0.75}$ ) were always above $30 \mathrm{~kg}$-sheep requirements reported by NRC (2007) (137g/animal.day, or $10.69 \mathrm{~g} / \mathrm{kg}^{0.75}$ ) indicating that the studied diets were composed by high quality components. Camurça et al. (2002) and Araújo et al. (2009) observed lower CCP ( 135g/animal.day) and BWG (74g/animal.day by Santa Inês and crossbred lambs fed $70 \%$ P. purpureum and $30 \%$ concentrate, when studying the substitution of the concentrate fraction by $O$. ficus indica bran). Consumption of CP reported by Castro et al. (2007) (205.88 g/animal.day or $19.02 \mathrm{~g} / \mathrm{kg}^{0.75}$ ) for Santa Inês lambs fed 60\% Manihot $s p$. hay were similar to the maximum CCP reported in the present study (209.33 g/animal.day or $\left.18.16 \mathrm{~g} / \mathrm{kg}^{0.75}\right)$, but resulted in higher BWG (253.35g/animal.day) than the reported in the present study (119.77 to 170.42g/animal.day).

Food conversion was not affected $(\mathrm{P}>0.05)$ by the (Op+Mim)mix inclusion in the diet. Mean FC were $8.20,7.78$ and 7.35 for 0,33 and $67 \%$, respectively, of $P$. purpureum substitution. Should all the $P$. purpureum fraction be substituted by (Op+Mim)mix, it is possible that FC may improve to values close to those in Parente et al. (2009). These authors found $\mathrm{FC}=6.82$ for lambs $1 / 2$ Santa Inês x $1 / 2$ SRD, fed $30 \%$ Cynodon spp., 32\% Leucena leucocephala hay and $38 \%$ disintegrated whole corn plants. Although this is different from the conventional concentrate : roughage fodder concept of diet using a tree-produced ingredient and whole corn plant, their components are highly water demanding. In contrast, the suggested diet with $100 \%$ substitution of $P$. purpureum by (Op+Mim)mix would have $60 \%$ of its weight composed by xerophytes adapted to tropical dry regions and probably would result in a FC even closer to the value reported by Parente et al. (2009). Indeed, leaves from xerophytes trees, such as $M$. glaziovii, can compose up to $60 \%$ of the diet of Santa Inês lambs and result in $\mathrm{FC}=4.92$ (CASTRO et al., 2007), showing the nutritional potential of some tree species.

Substitution of $P$. purpureum did not affected CNDF, CADF, CEE, and CW, but increased linearly CTC and CNFC (Table 4). The estimated increases were, respectively, 2.96 and $3.04 \mathrm{~g} /$ animal.day for each percentage point of $P$. purpureum substitution. Certainly, this resulted from the low fiber and highly palatable and digestible $O$. ficus indica bran in the mixture (BISPO et al., 2007). Mean CTC for $67 \%$ P. purpureum substitution (875.83g/animal.day) was similar to the observed by Bispo et al. (2007) - (858.50g/animal.day), when 
substituting $56 \%$ of $P$. purpureum by $O$. ficus indica in the diet of lambs, and by Castro et al. (2007) (813.04 g/animal.day), for lambs fed 60\% ( $M$. glaziovii) hay and $40 \%$ concentrate.

Substitution of $P$. purpureum hay affected linearly $(\mathrm{P}<0.05) \quad$ CEE expressed in $\mathrm{g} / \mathrm{kg}^{0.75}$ (Table 4). It increased from $4.85 \mathrm{~g} / \mathrm{kg}^{0.75}$ to $5.36 \mathrm{~g} / \mathrm{kg}^{0.75}$ when $P$. purpureum hay substitution increased from 0 to $67 \%$, respectively. Mean CEE was 57.33g/animal.day, lower than the CEE reported by Castro et al. (2007) (85.53 $\mathrm{g}$ /animal.day) for lambs fed $60 \%$ (M. glaziovii) hay and $40 \%$ concentrate. Certainly, this higher CEE results from a combination of factors, such as higher EE content of Manihot hay [7.34\%] as opposed to 5.42 or $5.20 \%$ in the diets with (Op+Mim)mix] (Table 2), as the reported $\mathrm{CDM}$ values reported by these authors (1160 to 1220 g/animal.day) were considered similar to the ones of the present study $(982.0$ to 1252.6g/animal.day).

Table 4. Means an regression equation for the variables (Y) CNDF ${ }^{\mathrm{a}}$, CADF, CEE e CW according to the levels (X) of substitution of Pennisetum purpureum hay by the balanced (weight) mixture of Opuntia ficus indica bran and Mimosa tenuiflora fine branches hay [(Op+Mim)mix] in the diet of male Santa Inês lambs, and respective significance level $(\mathrm{P})$ and coefficients of determination $\left(\mathrm{r}^{2}\right)$

\begin{tabular}{|c|c|c|c|c|c|c|}
\hline \multirow[t]{2}{*}{ Variable (Y) } & \multicolumn{3}{|c|}{$\begin{array}{l}\text { Levels of substitution of } P \text {. } \\
\text { purpureum by (Op+Mim)mix }\end{array}$} & \multirow[t]{2}{*}{ Regression equation } & \multirow[t]{2}{*}{$\mathrm{P}$} & \multirow[t]{2}{*}{$r^{2}$} \\
\hline & $0 \%$ & $33 \%$ & $67 \%$ & & & \\
\hline CNDF (g/an.day) & 523.50 & 548.00 & 523.60 & $Y=531.7$ & 0.998 & 0.0001 \\
\hline CNDF $\left(\mathrm{g} / \mathrm{kg}^{0.75}\right)$ & 48.33 & 49.16 & 45.83 & $Y=47.77$ & 0.211 & 0.0957 \\
\hline CADF (g/an.day) & 302.33 & 332.33 & 333.67 & $Y=322.77$ & 0.383 & 0.0477 \\
\hline CADF $\left(\mathrm{g} / \mathrm{kg}^{0.75}\right)$ & 27.83 & 29.66 & 29.33 & $Y=28.94$ & 0.165 & 0.1168 \\
\hline CTC (g/an.day) & 677.50 & 792.83 & 875.83 & $Y=683.470+2.958 X$ & 0.020 & 0.2908 \\
\hline CTC $\left(\mathrm{g} / \mathrm{kg}^{0.75}\right)$ & 62.67 & 71.33 & 76.83 & $Y=63.238+0.211 X$ & 0.000 & 0.6561 \\
\hline CNFC (g/an.dya) & 153.83 & 246.66 & 357.33 & $Y=151.331+3.038 X$ & 0.000 & 0.8271 \\
\hline CNFC $\left(\mathrm{g} / \mathrm{kg}^{0.75}\right)$ & 14.33 & 22.16 & 31.50 & $Y=14.123+0.256 X$ & 0.000 & 0.9701 \\
\hline CEE (g/an.day) & 52.50 & 58.50 & 61.0 & $Y=57.33$ & 0.169 & 0.1145 \\
\hline $\operatorname{CEE}\left(\mathrm{g} / \mathrm{kg}^{0.75}\right)$ & 4.85 & 5.25 & 5.36 & $Y=4.901+0.008 X$ & 0.043 & 0.2317 \\
\hline CW (g/an.day) & 2719 & 2943 & 3063 & $Y=2908.33$ & 0.486 & 0.0307 \\
\hline $\mathrm{CW}\left(\mathrm{g} / \mathrm{kg}^{0.75}\right)$ & 248.50 & 261.32 & 265.47 & $Y=258.43$ & 0.565 & 0.0210 \\
\hline
\end{tabular}

$\mathrm{CNDF}=$ consumption of neutral detergent fiber, CADF = consumption of acid detergent fiber, $\mathrm{CTC}=$ consumption of total carbohydrates, $\mathrm{CNFC}=$ consumption of non fibrous carbohydrates, $\mathrm{CEE}=$ consumption of ether extracts, $\mathrm{CW}=$ consumption of water.

Substitution of $P$. purpureum by (Op+Mim)mix affected quadratically CDDM, CDOM, CDCP, CDEE and CDTC $(\mathrm{P}<0.05) \quad$ (estimated minimum CDs between $33 \% \leq \mathrm{X} \leq 52 \%$ of substitution), decreased linearly CDNDF and CDADF $(\mathrm{P}<0.05)$, and had no effect on CDCE and CDNFC (P>0.05) - (Table $5)$.
Both CDNDF and CDADF decreased linearly by the inclusion of $(\mathrm{Op}+\mathrm{Mim}) \mathrm{mix}$ in the diet (Table 5). Cavalcanti et al. (2006) observed the same effect on CDNDF by including $O$. ficus indica as a substitute of Tifton grass in the diet of dairy cow. These authors explained that the inclusion of this NFC-rich forage decreases fiber content and increases the rate of food 
passage rate, reduces rumen $\mathrm{pH}$ and the quantity of cellulolytic bacteria in rumen, and ultimately decreases cellulose and fiber digestion.

Mean CDCP were, respectively, 76.72, 68.58 and $68.15 \%$ for 0,33 and $67 \%$ of $P$. purpureum substitution, with an estimated minimum value of $67.34 \%$ for
$\mathrm{X}=51.71 \%$. Probably, this reduction is due to the presence of compounds in (Op+Mim)mix, such as tannins. They may bind with proteins and hinder $\mathrm{CP}$ digestibility, although TT and CT contents in the diet (Table 2) were bellow the acceptable upper limit of 5\% (BEELEN et al., 2006).

Table 5. Means and regression equations of the coefficient of apparent digestibility (CD) of the bromatological components of the diets as a function of the substitution level (X) of Pennisetum purpureum hay by the balanced mixture of Opuntia fícus-indica bran and Mimosa tenuiflora fine branches hay in the diet of Santa Inês male lambs, significance levels $(\mathrm{P})$ for the linear $(\mathrm{L})$ and quadratic $(\mathrm{Q})$ components, and coefficients of determination $\left(\mathrm{r}^{2}\right.$ or $\left.\mathrm{R}^{2}\right)$ of the regression models

\begin{tabular}{|c|c|c|c|c|c|c|c|}
\hline \multirow{2}{*}{$\mathrm{CD}$} & \multicolumn{3}{|c|}{ Substitution levels $(\mathrm{X})$} & \multirow{2}{*}{ Regression equations } & \multicolumn{2}{|c|}{$\mathrm{P}$} & \multirow{2}{*}{$\mathrm{r}^{2}$ or $\mathrm{R}^{2}$} \\
\hline & $0 \%$ & $33 \%$ & $67 \%$ & & $\mathrm{~L}$ & $\mathrm{Q}$ & \\
\hline $\mathrm{DM}$ & 64.59 & 59.03 & 62.40 & $Y=64.595-0.299 X+0.004 X^{2}$ & 0.005 & 0.009 & 0.418 \\
\hline $\mathrm{OM}$ & 65.04 & 62.77 & 59.99 & $Y=65.040-0.308 X+0.004 X^{2}$ & 0.004 & 0.006 & 0.442 \\
\hline NDF & 52.02 & 37.40 & 33.37 & $Y=50.185-0.278 X$ & 0.000 & NS & 0.553 \\
\hline $\mathrm{ADF}$ & 42.65 & 30.12 & 19.06 & $Y=42.343-0.352 X$ & 0.000 & NS & 0.699 \\
\hline $\mathrm{CP}$ & 76.72 & 68.58 & 68.15 & $Y=76.720-0.362 X+0.004 X^{2}$ & 0.001 & 0.014 & 0.702 \\
\hline $\mathrm{CE}$ & 61.68 & 59.08 & 56.09 & $Y=58.95$ & 0.120 & 0.160 & 0.155 \\
\hline $\mathrm{EE}$ & 54.54 & 41.01 & 45.45 & $Y=54.548-0.676 X+0.008 X^{2}$ & 0.005 & 0.016 & 0.462 \\
\hline $\mathrm{TC}$ & 63.29 & 62.62 & 58.49 & $Y=63.297-0.277 X+0.004 X^{2}$ & 0.012 & 0.012 & 0.358 \\
\hline NFC & 83.72 & 90.03 & 90.06 & $Y=87.93$ & 0.058 & NS & 0.456 \\
\hline
\end{tabular}

$\mathrm{DM}=$ dry matter, $\mathrm{OM}=$ organic matter, $\mathrm{NDF}=$ neutral detergent fiber, $\mathrm{ADF}=$ acid detergent fiber, $\mathrm{CP}=$ crude protein, $\mathrm{EE}=$ ether extract, $\mathrm{TC}=$ total carbohydrates, $\mathrm{NFC}=$ no fibrous carbohydrates.

Substitution of $P$. purpureum had a quadratic effect on CDEE $(\mathrm{P}<0.05)$ with a minimum of $40.68 \%$ at $X=41.74 \%$ of substitution. Bringel et al. (2001) reported a similar effect on CDEE when substituting $P$. purpureum by dendê kernel cake in sheep diet. Probably, due to the presence of $M$. tenuiflora hay, mean CDEE values observed in the present study showed to be lower than the reported by Silva et al. (2007) (66.26 to $72.00 \%$ ) and Bispo et al. (2007) (57.47 to $65.63 \%)$ in lambs fed increasing levels of Manihot $s p$. and $O$. ficus indica, respectively.

Estimated minimum for CDTC was $58.50 \%$ for $\mathrm{X}=34.65 \%$ of $P$. purpureum substitution. This minimum slightly exceeded CDTC reported by Silva et al. (2007) (CDCT $=57.63 \%$ ) using $60 \%$ of Manihot sp. in the diet of lambs. However, any CDCT value showed in Table 5 or estimated from the respective regression equation were lower than the $\mathrm{CDCT}=73.03 \%$ reported by Bispo et al. (2007) in lambs fed $56 \%$ of O. ficusindica, certainly resulting from the better quality of the roughage fodder used by these authors $(87.75 \%$ of DM, $5.85 \%$ of CP, $80.67 \%$ of NDF, 54.81 of ADF, and $84.98 \mathrm{TC}$ ) as compared to the $P$. purpureum plus $(\mathrm{Op}+\mathrm{Mim}) \mathrm{mix}$.

It is concluded that Santa Inês lambs can consume a balanced (weight) 
mixture of Opuntia ficus indica bran and Mimosa tenuiflora fine branches hay in substitution of $67 \%$ of Pennisetum purpureum hay and keep satisfactory coefficients of digestibility and show a 50g-increase in daily body weight gain when compared to lambs fed a traditional $40 \%$ concentrate: $60 \%$ roughage fodder diet in which $P$. purpureum is the only roughage fodder component.

\section{REFERENCES}

ARAÚJO, G.G.L.; BADE, P.L.; MENEZES, D.R.; SOCORRO, E.P.; SÁ, J.L.; OLIVEIRA, G.J.C. Substituição da raspa de mandioca por farelo de palma forrageira na dieta de ovinos. Revista Brasileira de

Zootecnia, v.10, n.2, p. 448-459, 2009.

BEELEN, P.M.G.; BERCHIELLI, T.T.; BEELEN, R. ; ARAÚJO FILHO, J.; OLIVEIRA, S. G. Characterization of condensed tannins from native legumes of the Brazilian northeastern Semi-Arid. Science Agricultura, v.63, p.522-528, 2006.

BISPO, S.V.; FERREIRA, M.A.; VÉRAS, A.S.C.; BATISTA, A.M.V.; PESSOA, R.A.S.; BLEUEL, M.P. Palma forrageira em substituição ao feno de capim-elefante. Efeito sobre consumo, digestibilidade e características de fermentação ruminal em ovinos. Revista Brasileira de

Zootecnia, v.36, n.6, p.1902-1909, 2007.

BLAXTER, K.L. The Energy Metabolism of Ruminants. 3 ed. Hutchinson \& Company: London, p.329.1962.
BRINGEL, L.M.L.; NEIVA, J.N.M.; ARAÚJO, V.L.; BOMFIM, M.A.D.; RESTLE, J.; FERREIRA, A.C.H.; LÔBO, R.N.B. Consumo, digestibilidade e balanço de nitrogênio em borregos alimentados com torta de dendê em substituição à silagem de capim-elefante (Consumption, digestibility and nitrogen balance in lambs fed dendê kernel cake as a substitute of elephant grass silage).

Revista Brasileira de Zootecnia, v.40, p.1975-1983, 2011.

CAMURÇA, D.A.; NEIVA, J.N.M.; PIMENTEL, J.C.M.; VASCONCELOS, V.R.; LÔBO, R.N.B. Desempenho produtivo de ovinos alimentados com dietas à base de feno de gramíneas tropicais. Revista Brasileira de Zootecnia, v.31, n.5, p.2113-2122, 2002.

CASTRO, J.M.C.; SILVA, D.S.; MEDEIROS, A.N.; PIMENTA FILHO, E.C. Desempenho de cordeiros Santa Inês alimentados com dietas completas contendo feno de maniçoba. Revista Brasileira de Zootecnia, v.36, n.3, p.674-680, 2007.

CAVALCANTI, C.V.A.; FERREIRA, M.A.; CARVALHO, C.C.; VERAS, A.S.C.; LIMA, L.E.; SILVA, F.M. Palma forrageira (Opuntia fícus indica Mill) e uréia em substituição ao feno de tifton (Cynodon spp) em dietas de vacas holandesas em lactação. Acta Scientiarum-Animal Sciences, v.28, p.145-152, 2006.

CORDÃO, M.A.; BAKKE, O.A.; BAKKE, I.A.; RAMOS, C.T.C.; JÁCOME, I.S.C.; RAMOS, S.; LOPES, R.G.; BRITO, E.A. A jurema preta (Mimosa tenuiflora (Willd.) Poiret) e a favela (Cnidoscolus phyllacanthus (Muell. Arg.) Pax et K. Hoffm.) na alimentação de ovinos. Revista Pesquisa, v.1, n.1, p. 111-119, 2008. 
Rev. Bras. Saúde Prod. Anim., Salvador, v.14, n.4, p.xxx-xxx out./dez., 2013 http://www.rbspa.ufba.br ISSN 15199940

DETMANN, E.; SOUZA, M.A.; VALADARES FILHO, S.C.; QUEIROZ, A.C.; BERCHIELLI, T.T.; SALIBA, E.O.S.; CABRAL, L.S.; PINA, D.S.; LADEIRA, M.M.; AZEVEDO, J.A.G. Métodos para análise de alimentos. Visconde do Rio Branco, MG: Suprema, 2012. 214p.

HALL, M.B.; HOOVER, W.H.; JENNINGS, J.P.; MILLER, T.K.; WEBSTER. A method for partitioning neutral detergent-soluble carbohydrates. Journal of the Science of Food and Agriculture, v.79, n.15, p.2079-2086, 1999.

INSTITUTO BRASILEIRO DE GEOGRAFIA E ESTATÍSTICA IBGE. [2007]. Estatísticas sobre pecuária, rebanho e produção (Statistics on cattle raising, herd and production). Disponível em: < http://www.sidra.ibge.gov.br.htm> Acesso em: 26 Juli 2010.

MAIA, G. N. Caatinga: árvores e arbustos e suas utilidades (Caatinga: trees and shrubs and theis uses). São Paulo: D \& Z. 2004. 413p.

MELO, A.A.S.; FERREIRA, M.A.; VÉRAS, A.S.C.; LIRA, M.A.; LIMA, L.E.; VILELA, E.O.S.M.; ARAÚJO, P.R.B. Substituição.parcial do farelo de soja por uréia e palma forrageira (Opuntia fícus- indica Mill) em dietas para vacas em lactação: Desempenho. Revista Brasileira de Zootecnia, v.32, n.3, p.727-736, 2003.

MOREIRA, J.N.; LIRA, M.A.; SANTOS, M.V.F.; FERREIRA, M.A.; ARAÚJO, G.G.L.; FERREIRA, R.L.C.; SILVA, G.C. Caracterização da vegetação de Caatinga e da dieta de novilhos no Sertão de Pernambuco.

Pesquisa Agropecuária Brasileira, v.41, n.11, p.1643-1651, 2006.
NATIONAL RESEARCH COUNCILNRC. Nutrient requirements of sheep. 6.ed. Washington: National Academy of Science, 2007. 99p.

PARENTE, H.N.; MACHADO, T.M.M.; CARVALHO, F.C.; GARCIA, R.; ROGÉRIO, M.C.P.; BARROS, N.N.N.; ZANINE, A.M. Desempenho produtivo de ovinos em confinamento alimentados com diferentes dietas.

Arquivo Brasileiro de Medicina Veterinária e Zootecnia, v.61, n.2, p.460-466, 2009.

SILVA, D.S.; CASTRO, J.M.C.; MEDEIROS, A.N.; PIMENTA FILHO, E.C.; BARROSO, D.D. Feno de maniçoba em dietas para ovinos: consumo de nutrientes, digestibilidade aparente e balanço nitrogenado. Revista Brasileira de Zootecnia, v.36, n.5, p.1685-1690, 2007.

SNIFFEN, C.J.; O CONNOR, J.D.; Van SOEST, P.J.; FOX, D.G.; RUSSEL, J.B. A net carbohydrate and protein system for evaluating cattle diets: II. Carbohydrate and protein availability. Journal Animal Science, v.70, n.11, p.3562-3577, 1992.

STATSOFT, INC. Statistica for Windows 7.0 [Computer Program Manual]. Tulsa, OK, 2005.

Van SOEST, P.J.; ROBERTSON, J.B.; LEWIS, B.A. Symposium: carbohydrate methodology, metabolism, and nutritional implications in dairy cattle. Journal of Dairy Science, v.74, p.3583-3597, 1991.

VERAS, R.M.L.; FERREIRA, M.A.; CARVALHO, F.F.R.; VÉRAS, A.S.C. Farelo de Palma Forrageira (Opuntia ficus-indica Mill) em Substituição ao Milho. Digestibilidade Aparente de Nutrientes [Forage cactus (Opuntia 
Rev. Bras. Saúde Prod. Anim., Salvador, v.14, n.4, p.xxx-xxx out./dez., 2013 http://www.rbspa.ufba.br ISSN 15199940

ficus-indica Mill.) bran as a substitute of corn. Apparent digestibility of nutrients]. Revista Brasileira de Zootecnia, v.31, p.1302-1306, 2002.

ZIGUER, E.A.; TONIETO, S.R.; PFEIFER, L.F.M.; BERMUDES, R.F.; SCHWEGLER, E.; CORRÊA, M. N.; DIONELLLO, N.J.L. Resultados econômicos da produção de cordeiros em confinamento utilizando na dieta casca de soja associada a quatro fontes de nitrogênio não-protéico (Economic results of confined lambs fed soya peelings associated with four sources of non proteic nitrogen). Revista

Brasileira de Zootecnia, v.40, p.20582065, 2011.

Data de recebimento: $24 / 07 / 2013$

Data de aprovação: 10/12/2013 